\title{
THE EFFECTIVENESS OF AN INTEGRATED APPROACH IN THE TREATMENT OF OBESITY
}

Authors: I. Bourko ', M. Lushchyk ${ }^{1}$, A. Romanousky ', O. Isachkina', G. Korolenko², E. Kholodoval, L. Danilova ${ }^{1}$ Hospital: 1 - Belarusian Medical Academy of Postgraduate Education, Minsk Belarus;

2 - 10 City Hospital, Minsk Belarus.

Objectives:

\section{Methods:}

\section{Results:}

To assess the effectiveness of treatment of obesity using complex integrated approach. In the treatment of obesity were used: instructions of patient in healthy eating habits, diet, taking medication that reduces fat absorption - lipid-adsorbent tablets, polyglucosamine (L112). Survey of patients was conducted. The received data were analyzed.

61 obese patients (18 males and 43 females) were followed up for 12 weeks. Mean age $48.2 \pm 9.2$ year; BMI $34.9 \pm 5.21 \mathrm{~kg} / \mathrm{m} 2$. BMI, waist circumference (Wc) measurements, visceral fat content $(\%)$ before and after treatment were measured. Levels of total cholesterol (TC), triglycerides (TG), low density lipoproteins cholesterol (LDLC), high density lipoproteins cholesterol (HDLC) were also measured.

Followed up patients reached weight loss by $3.7 \%$, in BMI of $1.31 \mathrm{~kg} / \mathrm{m} 2$, waist circumference decreased by $4.15 \mathrm{~cm}$, visceral fat by $-0.68 \%$. Metabolic parameters improved. The maximum effect was achieved among the patients with university education, stable job, motivation to lose weight and among those that were keeping a food diary

An integrated approach in treatment of obesity is effective and consists of education of patients, presence of motivational reasons to lose weight, level of education, adherence to the principles of healthy eating and receiving supplementary medication to reduce fat absorption.

1. Mathus-Vliegen et al.: Prevalence, Pathophysiology, Heaith Consequences and Treatment Options of Obesity in the Elderly: A Guideline // Obes Facts. 2012. - №5. - P. 460-483.

2. Denke M.A. Obesity: Epidemiology, Pathophysiology, and Prevention. //N. Engl. J. Med. - 2007. - V. l. - N. 357. P. 2526-2532.

3. Данилова Л.И. Инсулинорезистентность, лептинорезистентность и артериальная гипертензия терапевтические изели при метаболическом синдроме.// Русский медицинский журнал. - 2007. - №3. - C.3644.

4. Management of obesity in adults: European clinical practice quidelines // Obes Facts. 2008. №1(2).- P. 106-116. 5. Лущик М.Л., Дудик Н.М., Сретенская Ж.Л. Данилова Л.И. Ожирение: руководство к действию Мн.: БелМАПО. - 2011. - 45 с.

6. Multifactorial intervention for weight loss. J.Postler, S.Plotz, A.Hahn. Institute of Food Science and Human Nutrition,Leibniz University Hannover, Germany.E-Mail: postler@nutrit:on.uni-hannover.de 